\title{
The role of nitrosative and oxidative stress in rainbow trout (Oncorhynchus mykiss) liver tissue applied mercury chloride $\left(\mathrm{HgCl}_{2}\right)$
}

\section{Civa klorür ( $\left.\mathrm{HgCl}_{2}\right)$ uygulanan gökkuşağı alabalığı (Oncorhynchus mykiss) karaciğer dokusunda nitrozatif ve oksidatif stresin rolü}

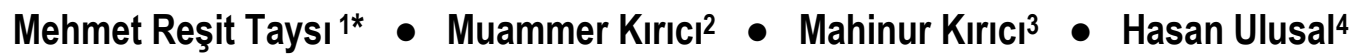 \\ Bünyamin Söğüt ${ }^{5}$ • Seyithan Taysı ${ }^{6}$ \\ ${ }^{1}$ Department of Fisheries, Faculty of Agriculture, Bingöl University, Bingöl, Turkey. \\ 2 Department of Veterinary Health, Vocational School of Technical Sciences, Bingöl University, Bingöl, Turkey. \\ ${ }^{3}$ Department of Chemistry, Faculty of Arts and Science, Bingöl University, Bingöl, Turkey. \\ ${ }^{4}$ Department of Medical Biochemistry, Medical School, Gaziantep University, Gaziantep, Turkey. \\ ${ }^{5}$ Department of Food Processing, Food Technology Program, Bandırma Vocational School, Bandırma \\ Onyedi Eylül University, Balıkesir, Turkey \\ ${ }^{6}$ Department of Medical Biochemistry, Medical School, Gaziantep University, Gaziantep, Turkey.
}

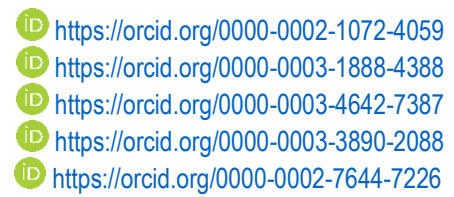

https://orcid.org/0000-0003-1251-3148

Taysı, M.R., Kırıcı, M., Kırıcı, M., Ulusal H., Söğüt, B. \& Taysı, S. (2021). The role of nitrosative and oxidative stress in rainbow trout (Oncorhynchus mykiss) liver tissue applied mercury chloride $\left(\mathrm{HgCl}_{2}\right)$. Ege Journal of Fisheries and Aquatic Sciences, 38(3), 269-273. DOI: 10.12714/egejfas.38.3.02

Abstract: The aim of this study was to determine oxidative stress caused by mercury chloride $\left(\mathrm{HgCl}_{2}\right)$ in rainbow trout (Oncorhynchus mykiss) liver tissue. For this purpose, the $\mathrm{LD}_{50}$ value of $\mathrm{HgCl}_{2}$ on rainbow trout was determined as $551 \mu \mathrm{g} / \mathrm{L}$. In the study, 40 fish in four groups were exposed to $25 \%$ and $50 \%$ (138 and $276 \mu \mathrm{m} / \mathrm{L})$ of the two subletal doses of $\mathrm{HgCl}_{2}$ for 2 and 7 days, with 10 fish $(n=10)$ in each group. To determine oxidative stress; peroxynitrite (ONOO-), total oxidant level (TOS), total antioxidant level (TAS), oxidative stress index (OSI) and malondialdehyde (MDA) were analyzed. In the study, it was observed that the differences between the groups in terms of ONOO-, TOS, TAS and OSI levels in the liver tissues was significant $(\mathrm{P}<0.05)$, however, this difference was not significant $(P>0.05)$ in terms of MDA values. As a result, it can be concluded that $\mathrm{HgCl}_{2}$ increases ONOO-, TOS, TAS, OSI and MDA levels in liver tissue and even small doses of mercury are toxic to fish.

Keywords: Oncorhynchus mykiss, mercury toxicity, oxidant/antioxidant, peroxynitrite, liver

Öz: Çalışmanın amacı, gökkuşağı alabalığı (Oncorhynchus mykiss) karaciğer dokusunda civa klorürün $\left(\mathrm{HgCl}_{2}\right)$ neden olduğu oksidatif stresi belirlemektir. $\mathrm{Bu}$ amaçla gökkuşağı alabalığı üzerine $\mathrm{HgCl}_{2}$ 'nin $\mathrm{LD}_{50}$ değeri $551 \mu \mathrm{g} / \mathrm{L}$ olarak tespit edilmiștir. Çalıșmada, her grupta 10 balık $(\mathrm{n}=10)$ olacak sekilde dört grupta toplam 40 adet balık 2 ve 7 gün süreyle $\mathrm{HgCl}_{2}$ 'ün iki subletal dozun $\% 25^{\prime}$ ine ve \%50' sine (138 ve $276 \mu \mathrm{g} / \mathrm{L}$ ) maruz bırakılmıştır. Oksidatif stresi belirlemek için peroksinitrit (ONOO-), toplam oksidan seviyesi (TOS), toplam antioksidan seviyesi (TAS), oksidatif stres indeksi (OSi) ve malondialdehit (MDA) tayinleri yapıımışıı. Çalışma sonucunda, genel olarak karaciğer dokularındaki ONOO-,TOS, TAS ve OSi düzeyleri açısından gruplar arasındaki fark istatistiksel olarak önemli $(P<0.05)$ cıkarken, MDA değerleri açısından bu fark istatistiksel olarak önemsiz $(P>0.05)$ çımıstır. Sonuc olarak $\mathrm{HgCl}_{2}$ 'nin karaciğer dokusunda ONOO-, TOS, TAS, OSİ ve MDA düzeylerini artırdığı ve civanın küçük dozlarının bile balıklar için toksik olduğu belirlenmiştir.

Anahtar kelimeler: Gökkuşağı alabalığı, civa toksisitesi, oksidan/antioksidan, peroksinitrit, karaciğer

\section{INTRODUCTION}

In parallel with the increase in industry, settlement and agricultural areas, the pollution of water resources also increases. It is causing pollution of water resources and disruption of natural balance; organic substances, metals, petroleum derivatives, artificial agricultural fertilizers, detergents, radioactive, pesticides, inorganic salts, artificial organic chemicals. Environmental conditions and water resources have to be considered and the metals causing environmental pollution are the most dangerous. The reason for this is due to the metals cannot be physically decomposed and persists for a long time. In particular, heavy metals, such as mercury, accumulate because they cannot be disposed of by natural physiological mechanisms and have a toxic effect if regulations are exceeded inside. In this accumulation, fish living in the water and people who feed on these fish may risk their lives (Dural et al., 2007; Gunes et al., 2019; Kasassi et al., 2008; Kırıcı et al., 2013).

Mercury is expressed as one of the 20 most toxic substances in the World. Today, mercury is widely used as a fungicide in agricultural applications and in the chlor-alkali industry, the manufacture of electrical equipment, the pharmaceutical industry, the cellulose and paper industry, and the production of plastics. Mercury is a metal that is highly toxic, even at trace levels, for all living things, both inorganic and organic form (Plessi et al., 2001). Mercury is mostly found as inorganic mercury compounds or in the aquatic 
environment as methylmercury $\left(\mathrm{CH}_{3} \mathrm{Hg}^{+}\right)$(Driscoll et al., 1994). There are two different ways for the bioaccumulation of mercury in aquatic organisms. These are the result of direct (by the metal in the water) or trophic exposures (by the metal of the food) (Boudou and Ribeyre, 1983). Mercury can also suppress important defense mechanisms of cells and cause lipid peroxidation by causing free oxygen species formation and oxidative stress (Berntssen et al., 2003). Mercury has a high affinity for the -SH groups of cellular biomolecules. For this reason, it can be attached to low molecular weight thiols and thyol containing proteins such as mercury, cysteine and glutathione after being taken into the body, and it can remain in tissues and organs for a long time, causing free radicals that cause lipid, protein and DNA oxidation (Perottoni et al., 2004). Considering that mercury compounds can easily spread in water, fish can be used as a good bioindicator of pollution in water ecosystems (Has-Schon et al., 2015).

Reactive oxygen species (ROS) such as superoxide radical $\left(\mathrm{O}_{2}-\right)$ and hydroxyl radical, and reactive nitrogen types (RNS) such as nitric oxide (NO), peroxynitrite $\left(\mathrm{ONOO}^{-}\right)$, are produced in fish as a result of intracellular metabolic processes and after exposure to genotoxic agents such as heavy metals. ROS or RNS-mediated oxidative or nitrosative injury occurs as a result of fish exposure to heavy metals (Berntssen et al., 2003; Mieiro et al., 2010; Wang et al., 2015). NO reacts with $\mathrm{O}_{2}$ to produce $\mathrm{ONOO}^{-}$anion, a powerful oxidant that can cause lipid peroxidation. ONOOinhibits mitochondrial electron transport, oxidizing thiol compounds and DNA (Powell et al., 2005). Malondialdehyde (MDA) is a product of lipid peroxidation in fish as well as in all highly vertebrates, and it is considered as one of the most important indicators of oxidative stress occurring in cell components (Morales et al.,2004).

Mercury chloride $\left(\mathrm{HgCl}_{2}\right)$, in industrial world in Turkey, is widely used both in scientific and agricultural purposes. For example, it is used as a fungicide in agriculture and as a topical antiseptic and disinfectant in medicine (Baser et al., 2003). So far, many researches have been done to determine the toxic effects of heavy metals, especially in relation to mercury compounds (Gül et al., 2008; Pandey et al., 2005; Terzi \& Verep, 2012; Thongra-ar et al., 2003; Verep et al., 2007). The aim of this study is to investigate the changes of nitrosative and oxidative stress (ONOO-, TOS, TAS, OSI and MDA) parameters that occur in rainbow trout liver tissue, where $\mathrm{HgCl}_{2}$ is applied.

\section{MATERIAL AND METHODS}

\section{Fish material and experimental application}

The application of the study was carried out at the Aquaculture Laboratory of Faculty of Agriculture and Molecular Biology Laboratory of the Faculty of Arts and Sciences in Bingöl University. Rainbow trout (Oncorhynchus mykiss) $(59.43 \pm 3.73 \mathrm{~g}$ and $17.24 \pm 1.64 \mathrm{~cm})$ was purchased from the trout facility of Keban district of Elazığ province and brought to the laboratory as live. The fish brought to the laboratory were placed in $600 \mathrm{lt}$ tanks and for their adaptation to the environment, it was fed with a commercial feed of $2 \%$ of its live weight twice a day for 15 days. During the study, water temperature, dissolved oxygen level and alkalinity were observed as $14 \pm 3{ }^{\circ} \mathrm{C}, 8.24 \pm 0.5 \mathrm{mg} / \mathrm{L}$ and $128 \pm 11 \mathrm{mg} / \mathrm{L}$, respectively, and total hardness was measured as $132 \pm 29$ $\mathrm{mg} / \mathrm{L}$ and $\mathrm{pH} 7.3 \pm 0.2$ as $\mathrm{CaCO}_{3}$.

In order to determine the $\mathrm{LD}_{50}$ value, $\mathrm{HgCl}_{2}$ was applied to Rainbow trout in the groups ( $n=10$ fish) with the dose of 100 , $200,500,750,1000$ and $1500 \mu \mathrm{g} / \mathrm{L}$. The fish in the groups were checked 3 times a day for 96 hours, and those who died were removed from the aquarium and noted. After 96 hours, the $\mathrm{LD}_{50}$ value was calculated as $551 \mu \mathrm{g} / \mathrm{L}$. Then, 2 subletal doses $\left(25 \% L_{50}=138 \mu \mathrm{g} / \mathrm{L}\right.$ and $\left.50 \% L_{50}=276 \mu \mathrm{g} / \mathrm{L}\right)$ were determined to apply. The fish were treated with subletal doses for 2 and 7 days. In the study, 10 fish were used in each group. No deaths occurred in any of the groups during the study. The use of fish and the experimental protocol were approved by Bingöl University Animal Experimentation Ethics Committee (Bingöl, Turkey).

\section{Preparation of homogen}

After euthanasia of the fish, liver tissues were removed by performing the necessary autopsy. Tissues were kept at $80^{\circ} \mathrm{C}$ in the freezer until use. Frozen liver tissue samples were homogenized individually in a 1:10 (w/v) ratio $(10 \mathrm{mM}$ Tris-buffer ( $\mathrm{pH}=7.4), 0.1 \mathrm{mM} \mathrm{NaCl}, 1 \%$ TritonX-100, $0.2 \%$ SDS, $2.5 \mathrm{mM}$ ethylenediaminetetraacetic acid.

\section{Determination of ONOO- value}

Evaluation of nitrosative stress status in liver tissue is obtained by determining $\mathrm{ONOO}^{-}$value. $\mathrm{ONOO}^{-}$value was measured by phenol nitration (Ahlatci et al., 2014; Al-Nimer et al., 2012; Vanuffelen et al., 1998). To obtain a final volume of $2 \mathrm{ml}, 10 \mu \mathrm{l}$ of sample was added to $5 \mathrm{mM}$ phenol in $50 \mathrm{mM}$ sodium phosphate buffer ( $\mathrm{pH} 7.4)$. After 2 hours of incubation in a dark place at $37^{\circ} \mathrm{C}, 15 \mu \mathrm{l}$ of $0.1 \mathrm{M} \mathrm{NaOH}$ was added and the absorbance of the samples at $412 \mathrm{~nm}$ wavelength was recorded. Nitrophenol yield was calculated from $\varepsilon=$ $4400 / \mathrm{M} / \mathrm{cm}$. Results were expressed as $\mu \mathrm{mol} / \mathrm{g}$ wet tissue. Biochemical measurements were made using a spectrophotometer (Shimadzu U 1601, Japan).

\section{Determination of TAS, TOS and OSI values}

TAS and TOS values of liver tissues were measured by Rel Assay brand commercial kits (Rel Assay Kit Diagnostics, Turkey). Trolox, a water-soluble analog of vitamin E, was used as calibrator for TAS tests. Results are expressed as mmol Trolox equiv/L (Erel, 2004). Hydrogen peroxide was used as calibrator for TOS tests. Results are expressed as umol $\mathrm{H}_{2} \mathrm{O}_{2}$ equiv./L. While calculating OSI, which is expressed as the percentage of the ratio of TOS levels to TAS levels, the mmol value in the unit of the TAS test was 
converted to $\mu \mathrm{mol}$ as in the TOS test (Erel, 2005). The results were calculated according to the formula below.

TOS, $\mu \mathrm{mol} \mathrm{H}_{2} \mathrm{O}_{2}$ equiv./L

OSI=

TAS, mmol Trolox equiv./Lx10

\section{MDA measurements}

MDA determination of tissue samples was made by method of Ohkawa et al. (1979) according to the method, 200 $\mu \mathrm{l}$ of each group was taken and $200 \mu \mathrm{l}$ of $8.1 \%$ SDS was added. Then it was kept in a boiling water bath at $95{ }^{\circ} \mathrm{C}$ for one hour and then cooled and vortexed by adding a mixture of $1 \mathrm{ml}$ distilled water and $5 \mathrm{ml}$ of $\mathrm{n}$-butanolpyridine in a ratio of 15: $1(\mathrm{v} / \mathrm{v})$. After centrifuging at $4000 \mathrm{rpm}$ for 15 minutes, the top organic layer was taken and measured spectrophotometrically at $532 \mathrm{~nm}$ wavelength, and the results were recorded in $\mathrm{nmol} / \mathrm{ml}$.

\section{Statistical analysis}

SPSS 20.0 package program was used to calculate the statistical analysis of the data obtained. One-way analysis of variance (oneway ANOVA) was used to determine the differences between the groups and Duncan Test was used to compare the groups.

\section{RESULTS}

As a result of the study, the 96 -hour $\mathrm{LD}_{50}$ value of $\mathrm{HgCl}_{2}$ in rainbow trout was $551 \mu \mathrm{g} / \mathrm{L}$. Groups were created based on the $\mathrm{LD}_{50}$ value. The groups were formed from five groups ( 1 control and 4 treatments); 2 and 7 days with 25\% (138 $\mu \mathrm{g} / \mathrm{L})$ and $50 \%(276 \mu \mathrm{g} / \mathrm{L})$ of the control group and $L D_{50}$.

The mean values of TAS, TOS, OSI, ONOO-and MDA of the control and experimental groups were statistically interpreted. While the difference between TAS, TOS, OSI and $\mathrm{ONOO}^{-}$values was statistically significant $(P<0.05)$, the difference in MDA levels was insignificant $(P>0.05)$.

When TAS values were analyzed, the highest group was found as Group $1(0.72 \mathrm{mmol} / \mathrm{L})$, while the lowest group was found as group 2 and group $3(0.62 \mathrm{mmol} / \mathrm{L})$. As a result of comparison of control and experimental groups in TAS values; There was no statistically difference between the control group (group 5) and other groups. However, when the groups were compared among themselves, a statistically significant difference was found between groups 1, 4 and groups 2, $3(\mathrm{P}<0.05)$.

When TOS values were examined, the highest group was $3(8.35 \mu \mathrm{mol} / \mathrm{L})$ and the lowest was $5(5.82 \mu \mathrm{mol} / \mathrm{L})$. Also, when the groups were compared, the difference between the control group and the other groups was found statistically significant $(P<0.05)$.

In terms of OSI values, the difference of group 3 from all other groups was statistically significant $(P<0.05)$. In MDA values, the difference of group 3 from all other groups was statistically significant $(\mathrm{P}<0.05)$.

TAS (mmol/L), TOS ( $\mu \mathrm{mol} / \mathrm{L})$, OSI, ONOO- $(\mathrm{mmol} / \mathrm{L})$ and MDA (nmol/mg protein) values of liver samples are given in Table 1.

Table 1. TAS, TOS, OSI, ONOO- and MDA values of liver samples

\begin{tabular}{|c|c|c|c|c|c|}
\hline & \multicolumn{5}{|c|}{ Trial Groups ( $\bar{x} \pm S D)^{*}$} \\
\hline & 1 & 2 & 3 & 4 & 5 \\
\hline TAS & $0.72 \pm 0.06^{b}$ & $0.62 \pm 0.06^{a}$ & $0.62 \pm 0.05^{\mathrm{a}}$ & $0.70 \pm 0.05^{b}$ & $0.67 \pm 0.08^{\mathrm{ab}}$ \\
\hline TOS & $6.54 \pm 0.95^{\mathrm{ab}}$ & $7.07 \pm 0.83^{b c}$ & $8.35 \pm 0.49^{d}$ & $7.54 \pm 0.45^{c}$ & $5.82 \pm 0.53^{a}$ \\
\hline OSI & $90.42 \pm 17.85^{\mathrm{a}}$ & $113.08 \pm 10.58^{b}$ & $134.42 \pm 10.25^{c}$ & c $107.92 \pm 8.40^{b}$ & $87.39 \pm 9.60^{a}$ \\
\hline ONOO- & $34.64 \pm 10.04^{a}$ & $41.79 \pm 4.94^{\mathrm{ab}}$ & $54.64 \pm 14.17^{\mathrm{bc}}$ & $70.39 \pm 26.98^{c}$ & $33.61 \pm 2.38^{a}$ \\
\hline MDA & $12.40 \pm 3.15^{\mathrm{a}}$ & $17.10 \pm 6.84^{a}$ & $31.06 \pm 12.38^{b}$ & $14.00 \pm 3.81^{\mathrm{a}}$ & $9.69 \pm 2.80^{\mathrm{a}}$ \\
\hline
\end{tabular}

*The difference between average values carrying different letters in the same line is statistically significant $(p<0.05)$.

TAS=Total Antioxidant Level, TOS=Total Oxidant Level, OSI=Oxidative Stress Index, ONOO=Peroxynitrite, MDA=Malondialdehyde, 1= 25\% LC50 2 Days, 2=50\% LC50 2 Days, $3=25 \%$ LC50 7 Days, 4=50\% LC50 7 Days, 5=Control group

\section{DISCUSSION}

Mercury is a heavy metal that is not necessary for biological functions and can be very toxic even at very low levels. Given that a total of 40,000-50,000 tons of mercury reaches the atmosphere and 4,000 tons of water every year, mercury poses a great risk for humans and other living things. Mercury is listed by the International Chemical Safety Program (IPCS) as one of the most dangerous chemicals in the environment (Gilbert and Grantwebster, 1995). This heavy metal is also included in the most dangerous xenobiotic class with its toxicological effects such as neurotoxic, embryotoxic and cytotoxic, and wide spread and permanence in the environment (Gundacker et al., 2006). Mercury mixed with water is converted to methylciva by bacteria and organisms. Planktons get into the food chain with small fish and mussels that eat them, and large fish and marine mammals that feed on small fish (Güven et al., 2004). The increase in water temperature increases the solubility of the mercury in the water in the summer and affects the increase of the mercury concentration in the fish (Gül et al., 2004). Mercury accumulates in many fish species, causing kidney and liver lesions, endocrine disorders and changes in the membranes of cells in the central nervous system (Bano and Hasan, 1990; Iliopoulou-Georgudaki and Kotsanis, 2001; Veena et al., 1997).

Since hepatic blood flow is proportionally slower than cardiac blood flow in fish liver, it is more sensitive to damage caused by toxic substances. Also, because the liver is a detoxification organ, heavy metals accumulate most in this organ. Indeed, in a study, it was observed that the highest 
elimination percentage (up to $64 \%$ in the liver, $20 \%$ in the brain and $3 \%$ in the muscle) was recorded in the liver in European seabasses exposed to $\mathrm{MeHg}$ for 28 days (Maulvault et al., 2016). Hg can cause liver damage, as shown in bream (Guardiola et al., 2016), Salvelinus alpinus (de Oliveira Ribeiro et al., 2002) and tiger fish (Elia et al., 2003). In a study (Guardiola et al., 2016), it was stated that MeHg exposure to sea bream (Sparus aurata) fish increased SOD, CAT activities and ROS levels in blood serum while decreasing antioxidant potential. In our study, it was determined that rainbow trout (Oncorhynchus mykiss) increased the oxidative stress parameters of $\mathrm{HgCl}_{2}$ in liver tissue. Besides, it was found that rainbow trout of $\mathrm{HgCl}_{2}$ caused toxic effects on liver tissue.

The most important feature of the antioxidant defense system is that all components of the system act in a way that creates a synergy against reactive oxygen types (Chaudiere and Ferrari-lliou, 1999). Therefore, all antioxidants are vital in ensuring homeostasis in living things (Doyotte et al., 1997). As a result of the oxidant and antioxidants in the blood acting together, more oxidant and antioxidant effects occur than each one creates alone. For this reason, it is reported that TOS and TAS measurement may be more useful to determine the total oxidant/antioxidant balance instead of measuring the oxidant and antioxidants individually (Erel, 2004, 2005). Indeed, there are many studies in this direction. For example; Doğan et al. (2011) investigated the biochemical effects of subletal concentrations of fenpyroximate acaricide in the liver tissue of adult guppies by looking at TAS and TOS values, they noted that the doses of subletal acaricide administered did not cause any changes in antioxidant activity, and 25 and $50 \mu \mathrm{g} / \mathrm{l}$ acaricide caused oxidative stress. Kaya et al (2014), in their study investigating the effect of tebuconazole used as fungicide in Cyprinus carpio (L., 1758) on serum TAS and TOS levels, found that serum TAS levels decreased in groups treated with

\section{REFERENCES}

Ahlatci, A., Kuzhan, A., Taysi, S., Demirtas, O.C., Alkis, H.E., Tarakcioglu, M., Demirci, A., Caglayan, D., Saricicek, E. \& Cinar, K. (2014). Radiation-modifying abilities of Nigella sativa and thymoquinone on radiation-induced nitrosative stress in the brain tissue. Phytomedicine 21, 740-744. DOI: 10.1016/j.phymed.2013.10.023

Al-Nimer, M.S., Al-Ani F.S. \& Ali F.S. (2012). Role of nitrosative and oxidative stress in neuropathy in patients with type 2 diabetes mellitus. Journal of Neurosciences in Rural Practice 3, 41-44. DOI: 10.4103/0976-3147.91932

Bano, Y. \& Hasan M. (1990). Histopathological lesions in the body organs of cat-fish (Heteropneustes fossilis) following mercury intoxication. Journal of Environmental Science and Health, Part B 25, 67-85. DOI: 10.1080/03601239009372677

Baser, S., Erkoc, F., Selvi, M. \& Kocak, O. (2003). Investigation of acute toxicity of permethrin on guppies Poecilia reticulata. Chemosphere 51, 469-474. DOI: 10.1016/S0045-6535(03)00033-X

Berntssen, M.H.G., Aatland, A. \& Handy, R.D. (2003). Chronic dietary mercury exposure causes oxidative stress, brain lesions, and altered behaviour in Atlantic salmon (Salmo salar) parr. Aquatic Toxicology 65, 55-72. DOI: 10.1016/S0166-445X(03)00104-8 tebuconazole compared to the control group and increased TOS levels. In this study, while the TOS values were increasing, no statistically significant difference was found between the control group and the other groups in TAS values. However, a statistically significant difference was found between TAS and time-dependent groups in TAS values $(P<0.05)$.

MDA is considered as indicators of oxidative stress caused by the damage caused by free radicals to the membrane complements of cells (Yonar et al., 2016). Many researchers have reported a relationship between MDA and $\mathrm{HgCl}_{2}$-induced stress in fish (Fathi et al., 2018; Ibrahim, 2015; Thirumavalavan, 2010). The findings of this study showed that liver MDA levels were higher than the control group (Table 1). This is most likely explained by the production of hyperreactive oxygen species, which may be associated with a lowering of the antioxidant enzyme level and thus lead to lipid peroxidation.

As a result, it has been determined that $\mathrm{HgCl}_{2}$ increases ONOO-, TOS, TAS, OSI and MDA levels in liver tissue and even small doses of mercury are toxic to fish. These results show the effect of $\mathrm{HgCl}_{2}$ on the exhaustion of antioxidant mechanisms. More studies are needed to clarify the basic mechanisms in $\mathrm{HgCl}_{2}$ 's long-term toxicity profile in rainbow trout and to make sense of the toxicity mechanism. This study plays a role in understanding our $\mathrm{HgCl}_{2}$ exposure, its potential impact and improving our knowledge of $\mathrm{HgCl}_{2}$ ecotoxicology and risk assessment. However, it is a known fact that some fish species are more susceptible to mercury toxicity than others. Therefore, toxicological pathology caused by mercury in fish is affected by factors such as species, age, environmental conditions, exposure time and exposure concentration. Considering these factors, studies should be carried out in different doses and durations in different fish to make sense of the toxicity mechanism of $\mathrm{HgCl}_{2}$ on fish.

Boudou, A. \& Ribeyre, F. (1983). Contamination of aquatic biocenoses by mercury compounds an experimental ecotoxicological approach. In J. 0. Nriagu (Ed.) Aquatic Toxicology, J Wiley and Sons (New York), pp. 117136.

Chaudiere, J. \& Ferrari-lliou, R. (1999). Intracellular antioxidants: from chemical to biochemical mechanisms. Food and Chemical Toxicology 37, 949-962. DOI: 10.1016/S0278-6915(99)00090-3

de Oliveira Ribeiro, C.A., Belger, L., Pelletier, E. \& Rouleau, C. (2002). Histopathological evidence of inorganic mercury and methyl mercury toxicity in the arctic charr (Salvelinus alpinus). Environmental Research 90, 217-225. DOI: 10.1016/S0013-9351(02)00025-7

Doğan, N., Yazıcı, Z. \& Şişman, T. (2011). Lepistes balığının karaciğeri üzerine fenpiroksimat akarisiti'nin biyokimyasal etkileri. Balıkesir Üniversitesi Fen Bilimleri Enstitüsü Dergisi 13: 1-8.

Doyotte, A., Cossu, C., Jacquin, M.C., Babut, M. \& Vasseur, P. (1997). Antioxidant enzymes, glutathione and lipid peroxidation as relevant biomarkers of experimental or field exposure in the gills and the digestive gland of the freshwater bivalve Unio tumidus. Aquatic Toxicology, 39(2), 93-110. DOI: 10.1016/S0166-445x(97)00024-6 
Driscoll, C.T., Yan, C., Schofiel, L., Munson, R. \& Holsapple, J. (1994). The mercury cycle and fish in the adirondak lakes. Environmental Science and Technology, 28, 136-143. DOI: 10.1021/es00052a003

Dural, M., Goksu, M.Z.L. \& Ozak, A.A. (2007). Investigation of heavy metal levels in economically important fish species captured from the Tuzla lagoon. Food Chemistry, 102(1), 415-421. DOI: 10.1016/j.foodchem.2006.03.001

Elia, A.C., Galarini, R., Taticchi, M.I., Dorr, A.J. \& Mantilacci, L. (2003). Antioxidant responses and bioaccumulation in Ictalurus melas under mercury exposure. Ecotoxicology and Environmental Safety, 55(2), 162 167. DOI: 10.1016/s0147-6513(02)00123-9

Erel, O. (2004). A novel automated direct measurement method for total antioxidant capacity using a new generation, more stable ABTS radical cation. Clinical Biochemistry, 37(4), 277-285. DOI: 10.1016/j.clinbiochem.2003.11.015

Erel, O. (2005). A new automated colorimetric method for measuring total oxidant status. Clinical Biochemistry, 38(12), 1103-1111. DOI: 10.1016/j.clinbiochem.2005.08.008

Fathi, M., Binkowski, L.J., Azadi, N.A., Hamesadeghi, U. \& Mansouri, B. (2018). Co-exposure effects of mercury chloride $\left(\mathrm{HgCl}_{2}\right)$ and silver nanoparticles (Ag-NPs) on goldfish (Carassius auratus): Histopathological changes, oxidative stress response, and bioaccumulation. Desalination and Water Treatment, 105, 264-272. DOI: 10.5004/dwt.2018.21994

Gilbert, S.G. \& Grantwebster, K.S. (1995). Neurobehavioral effects of developmental methylmercury Exposure. Environmental Health Perspectives, 103, 135-142. DOI: 10.2307/3432363

Guardiola, F.A., Chaves-Pozo, E., Espinosa, C., Romero, D., Meseguer, J., Cuesta, A. \& Esteban, M. A. (2016). Mercury accumulation, structural damages, and antioxidant and immune status changes in the gilthead seabream (Sparus aurata L.) exposed to methylmercury. Archives of Environmental Contamination and Toxicology, 70(4), 734-746. DOI: 10.1007/s00244-016-0268-6

Gundacker, C., Komarnicki, G., Zodl, B., Forster, C., Schuster, E. \& Wittmann, K. (2006). Whole blood mercury and selenium concentrations in a selected Austrian population: Does gender matter? Science of the Total Environment, 372(1), 76-86. DOI: 10.1016/j.scitotenv.2006.08.006

Gunes, M., Sokmen, T. O. \& Kirici, M. (2019). Determination of some metal levels in water, sediment and fish species of Tercan Dam Lake, Turkey. Applied Ecology and Environmental Research, 17(6), 14961-14972. DOI: 10.15666/aeer/1706_1496114972

Gül, A., Yılmaz, M. \& Selvi, M. (2004). The study of the toxic effects of mercury-II-chloride. Gazi Üniversitesi Fen Bilimleri Dergisi, 17(4), 53-58.

Gül, A., Yılmaz, M. \& Uzel, N. (2008). Acute toxic effect of mercury II chloride in Capoeta tinca (Heckel. 1843), living in the Kirmir stream of Sakarya river. Kastamonu Educational Journal, 16, 199-206.

Güven, A., Kahvecioğlu, Ö., Kartal, G. \& Timur, S. (2004). Metallerin çevresel etkileri- III. Metalurij Dergisi 17(138), 64-71.

Has-Schon, E., Bogut, I., Vukovic, R., Galovic, D., Bogut, A. \& Horvatic, J. (2015). Distribution and age-related bioaccumulation of lead $(\mathrm{Pb})$, mercury $(\mathrm{Hg})$, cadmium $(\mathrm{Cd})$, and arsenic $(\mathrm{As})$ in tissues of common carp (Cyprinus carpio) and European catfish (Sylurus glanis) from the Busko Blato reservoir (Bosnia and Herzegovina). Chemosphere, 135, 289-296. DOI: 10.1016/j.chemosphere.2015.04.015

Ibrahim, A.T.A. (2015). Effects of mercury chloride on oxidative stress biomarkers of some tissues of the african catfish Clarias gariepinus (Burchell, 1822). Journal of Veterinary Science and Technology, 6(4), 15. DOI: 10.4172/2157-7579.1000242

Kasassi, A., Rakimbei, P., Karagiannidis, A., Zabaniotou, A., Tsiouvaras, K., Nastis, A. \& Tzafeiropoulou, K. (2008). Soil contamination by heavy metals: Measurements from a closed unlined landfill. Bioresource Technology, 99(18), 8578-8584. DOI: 10.1016/j.biortech.2008.04.010

Kaya, I., Y.lmaz, M., Koç, E., Deveci, H.A., Ersan, Y. \& Karapehlivan, M. (2014). Tebukonazol (fungusit) uygulanan Cyprinus carpio (L. 1758)'da serum total antioksidan, oksidan ve sialik asit düzeylerinin incelenmesi. Journal of FisheriesSciences.com, 8(3), 214-219.

Kırıcı, M., Taysi, M.R., Bengü, A. Ş. \& İspir, Ü. (2013). Determination of accumulation concentrations of some metals in the muscle tissue of Capoeta trutta (Heckel, 1843) captured in the Murat River. Journal of Erzincan University Institute of Science, 6(1), 115-124.
lliopoulou-Georgudaki, J. \& Kotsanis, N. (2001). Toxic effects of cadmium and mercury in rainbow trouth (Oncorhynchus mykiss): a short-term bioassay. Bulletin of Environmental Contamination and Toxicology. 66, 77-85. DOI: $10.1007 / \mathrm{s} 0012800208$

Maulvault, A.L., Custodio, A., Anacleto, P., Repolho, T., Pousao, P., Nunes, M. L. \& Marques, A. (2016). Bioaccumulation and elimination of mercury in juvenile seabass (Dicentrarchus labrax) in a warmer environment. Environmental Research, 149, 77-85

DOI: 10.1016/j.envres.2016.04.035

Mieiro, C.L., Ahmad, I., Pereira, M.E., Duarte, A.C. \& Pacheco, M. (2010). Antioxidant system breakdown in brain of feral golden grey mullet (Liza aurata) as an effect of mercury exposure. Ecotoxicology, 19(6), 10341045. DOI: $10.1007 / \mathrm{s} 10646-010-0485-0$

Morales, A.E., Pèrez-Jimènez, A., Hidalgo, M.C., Abellán, E. \& Gabriel, C.G. (2004). Oxidative stres and antioxidant defenses after prolonged starvation in Dentex dentex liver. Comporative Biochemistry and Physiology, 139(7), 153-161.

Ohkawa, H., Ohishi, N. \& Yagi, K. (1979). Assay for lipid peroxides in animal tissues by thiobarbituric acid reaction. Analytical Biochemistry, 95(2), 351-358. DOI: 10.1016/0003-2697(79)90738-3

Pandey, S., Kumar, R., Sharma, S., Hagpure, N.S., Srivastava, S.K., Verma, M.S. (2005). Acute toxicity bioassays of mercuric chloride and malathion on air-breathing fish Channa punctatus (Bloch). Ecotoxicology and Environmental Safety 61: 114-120. DOI: 10.1016/j.ecoenv.2004.08.004

Perottoni, J., Lobato, L.P., Silveira, A., Batista, J., Rocha, T. \& Emanuelli, T. (2004). Effects of mercury and selenite on delta-aminolevulinate dehydratase activity and on selected oxidative stress parameters in rats. Environmental Research, 95(2), 166-173. DOI: 10.1016/j.envres.2003.08.007

Plessi, M., Bertelli, D. \& Monzani, A. (2001). Mercury and selenium content in selected seafood. Journal of Food Composition and Analysis, 14, 461467. DOI: $10.1006 /$ ffca.2001.1003

Powell, C.L., Swenberg, J. A. \& Rusyn, I. (2005). Expression of base excision DNA repair genes as a biomarker of oxidative DNA damage. Cancer Letters, 229(1), 1-11. DOI: 10.1016/j.canlet.2004.12.002

Svobodova, Z., Luskova, V., Drastichova, J., Svoboda, M. \& Zlabek, V. (2003). Effect of deltamethrin on haematological indices of common carp (Cyprinus carpio L.). Acta Veterinaria Brno, 72(1), 79-85. DOl: 10.2754/avb200372010079

Terzi, E. \& Verep, B. (2012). Effects of water hardness and temperature on the acute toxicity of mercuric chloride on rainbow trout (Oncorhynchus mykiss). Toxicology and Industrial Health, 28(6), 499-504. DOI: $10.1177 / 0748233711416943$

Thirumavalavan, R. (2010). Effect of mercury on lipid peroxidation and antioxidants in gill tissue of fresh water fish, labeo rohita. International Journal of Recent Scientific Research, 5, 122-124.

Thongra-ar, W., Parkpian, P. \& Tang, A. (2003). Toxicity of mercury to growth and survival of seabass larvae Lates carcarifer and the modyfing of effects of salinity. ScienceAsia, 29, 2009-2019.

Vanuffelen, B.E., Van Der Zee, J., De Koster, B.M., Vansteveninck, J. \& Elferink, J.G. (1998). Intracellular but not extracellular conversion of nitroxyl anion into nitric oxide leads to stimulation of human neutrophil migration. Biochemical Journal, 330(2), 719-722. DOl: $10.1042 / b j 3300719$

Veena, K.B., Radhakrishnan, C.K. \& Chacko, J. (1997). Heavy metal induced biochemical effects in an estuarine teleost. Indian Journal of Marine Sciences, 26(1), 74-78.

Verep, B., Besli, E. S., Altinok, I. \& Mutlu, C. (2007). Assessment of mercuric chloride toxicity on rainbow trouts (Oncorhynchus mykiss) and chubs (Alburnoides bipunctatus). Pakistan Journal of Biological Sciences, 10(7), 1098-1102. DOI: 10.3923/pjbs.2007.1098.1102

Wang, B., Feng, L., Jiang, W.D., Wu, P., Kuang, S.Y., Jiang, J. \& Zhou, X.Q. (2015). Copper-induced tight junction mRNA expression changes, apoptosis and antioxidant responses via NF-kappa B, TOR and Nrf2 signaling molecules in the gills of fish: Preventive role of arginine. Aquatic Toxicology, 158, 125-137. DOI: 10.1016/j.aquatox.2014.10.025

Yonar, M.E., Ispir, U., Mise Yonar, S. \& Kirici, M. (2016). Effect of copper sulphate on the antioxidant parameters in the rainbow trout fry, Oncorhynchus mykiss. Cellular and Molecular Biology, 62(6), 55-58. 